\title{
Pemeriksaan Hemodinamik Ekokardiografi pada Kasus Kegawatan dan Kritikal Jantung Seri IIl: Penilaian Hemodinamik Jantung Kanan
}

\author{
Amiliana M Soesanto
}

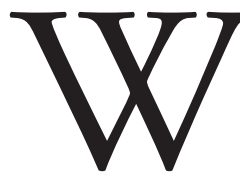

alaupun sering terabaikan, fungsi jantung kanan dan sirkulasi pulmoner mempunyai peranan penting dalam keseluruhan sistem sirkulasi. Tidak jarang kasus-kasus kritikal disebabkan karena kegagalan sirkulasi jantung kanan. Pada seri III forum ekokardiografi ini akan dibahas penilaian hemodinamik jantung kanan dengan ekokardiografi untuk kasus-kasus kritikal sehingga akan diutamakan cara pemeriksaan yang praktis, sederhana, dan cepat.

\section{Penilaian fungsi ventrikel kanan}

Ventrikel kanan memiliki geometri yang unik dan berbeda dengan ventrikel kiri. Oleh karena ini pengukuran fungsi sistolik ventrikel kanan berbeda dengan ventrikel kiri. Ada beberapa cara pengukuran fungsi sistolik ventrikel kanan. Namun pada artikel hanya cara pemeriksaan yang sederhana, cepat dan praktis yang akan diulas. Pemeriksaan tersebut antara lain sebagai berikut;

Alamat korespondensi:

Dr. dr. Amiliana M Soesanto, SpJP. Departemen Kardiologi dan Kedokteran Vaskuler FKUI dan Pusat Jantung Nasional Harapan, Kita, JI S Parman Kav 87 Jakarta I I420, E-mail: amiliana I4@gmail.com

\section{Trikuspid Anular Plane Systolic Excursion (TAPSE)}

Pemeriksaan TAPSE menggambarkan fungsi kontraksi longitudinal ventrikel kanan. Kursor M-mode diletakkan di anulus trikuspid pada pandangan apikal 4 ruang, seperti terlihat pada Gambar 1 kiri. Pada gambaran M-moda akan terlihat gelombang sesuai dengan gerakan anulus trikuspid selama siklus kardiak. Jarak titik anulus dalam kondisi sistolik dan diastolik dinamakan TAPSE (satuan $\mathrm{mm}$ atau $\mathrm{cm}$ ), seperti terlihat pada Gambar 1 kanan.

\section{Pulse Wave Tissue Doppler Imaging (PW TDI)}

Pemeriksaan fungsi sistolik (longitudinal) ventrikel kanan lain yang dapat dikerjakan adalah dengan mengukur kesepatan gerak anulus trikuspid pada fase sistolik (s') dalam satuan $\mathrm{cm} / \mathrm{mnt}$ atau $\mathrm{m} / \mathrm{mnt}$, pada pandangan apikal 4 ru ang seperti yang terlihat pada Gambar 2. Kontraktilitas ventrikel kanan dianggap normal bila s' $\geq 11.5 \mathrm{~cm} / \mathrm{mnt}$.

\section{Penilaian secara visual}

Secara praktis, kontraktilitas ventrikel kanan dapat dinilai dengan cara visual. Walaupun pemeriksaan ini bersifat subjektif, namun pada pemeriksa yang sudah berpengalaman, penilaian ini dapat memberikan kesan bagaimana kontraktilitas ventrikel kiri 


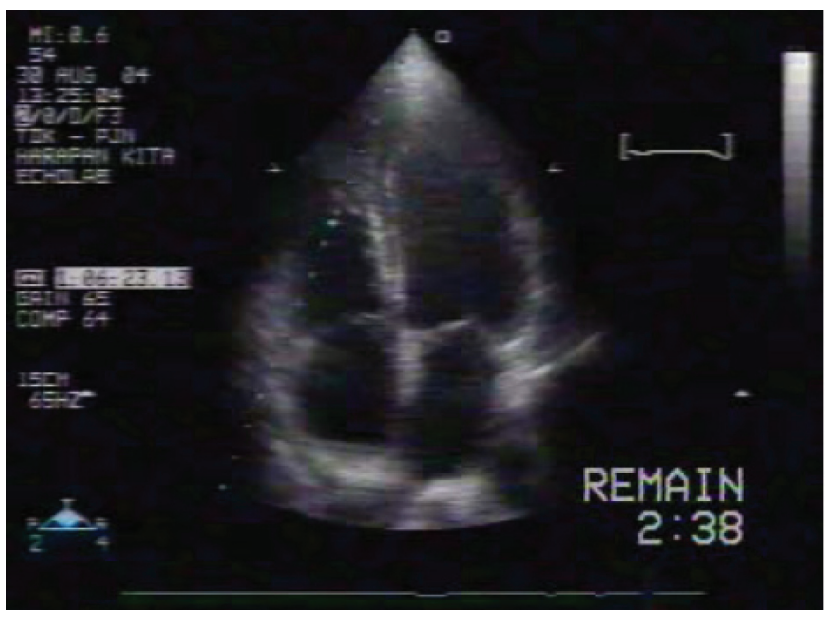

Gambar 1A. Pandangan apikal 4 ruang dengan kursor M-mode memotong anulus trikuspid.

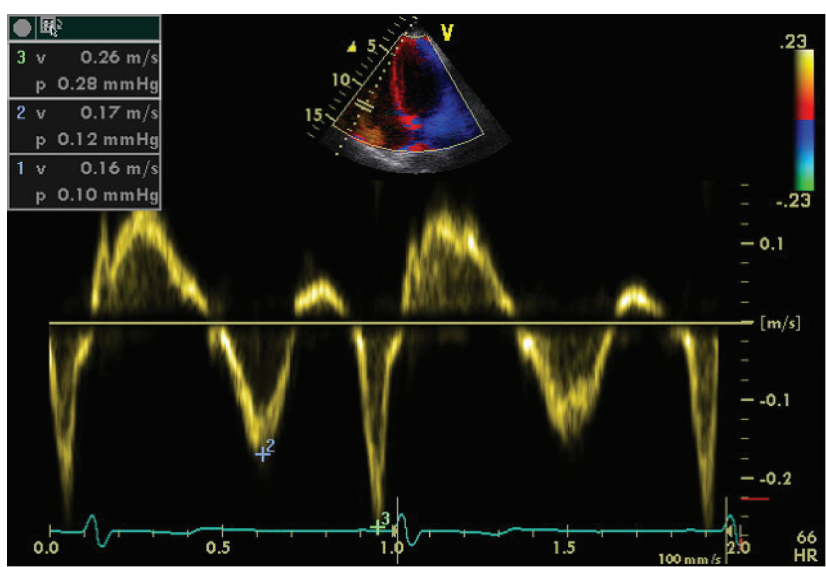

Gambar 2. Pengukuran s'ventrikel kanan dilakukan dengan cara meletakkan sampel volume pada dinding bebas anulus trikuspid.

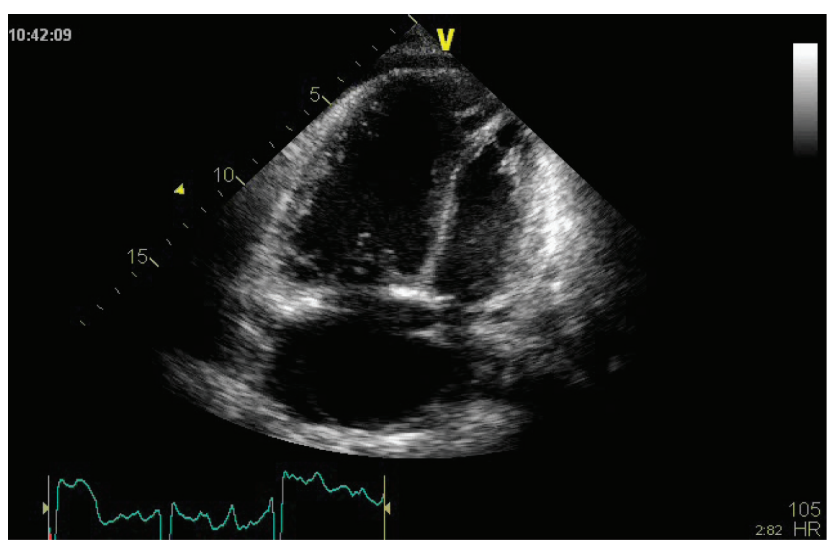

Gambar 3. Perbandingan dimensi ruang ventrikel kanan terhadap kiri.

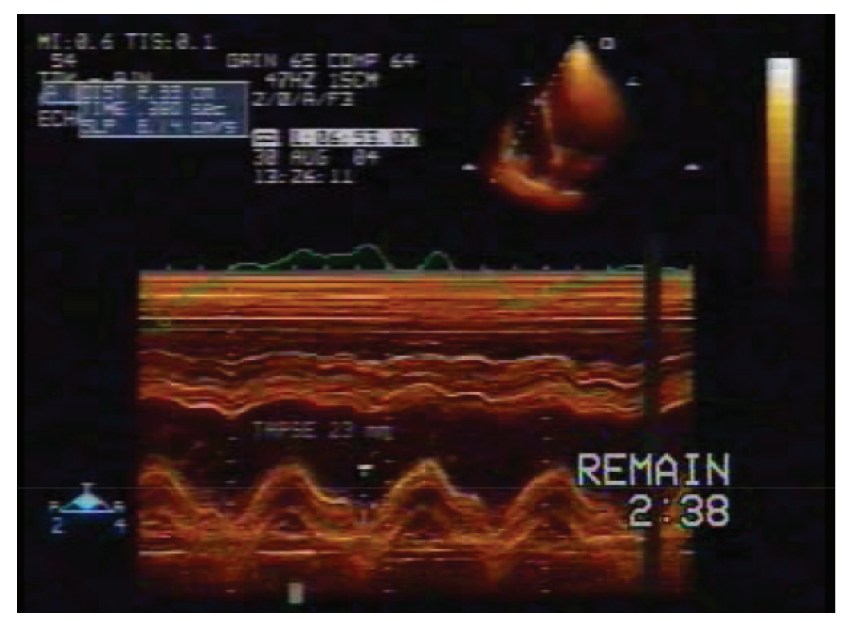

Gambar 1B. Gelombang gerakan anulus trikuspid dalam siklus kardiak.

yang penting pada kasus kegawatan dan kritikal. Secara visual dimensi ventrikel kanan dapat dinilai dengan membandingkannya terhadap ventrikel kiri. Pada keadaan dimensi ventrikel kiri yang normal, perbandingan ventrikel kanan dan ventrikel kiri $\geq 1$ menunjukkan adanya dilatasi ventrikel kanan, seperti yang terlihat pada Gambar 3.

\section{Penilaian hemodinamik jantung kanan}

\section{Pengukuran tekanan sistolik arteri pulmonal}

Ekokardiografi dapat memperkirakan tekanan sistolik, diastolik, dan tekanan rerata arteri pulmonal. Bila tidak ada stenosis pulmonal,tekanan sistolik ventrikel kanan sama dengan tekanan sistolik a. Pulmonal. Tekanan sistolik ventrikel kanan diukur dengan menjumlahkan gradien sistolik regurgitasi trikuspid (TVG) dengan tekanan atrium kanan (RAap). Sedangkan gradien sistolik regurgitasi trikuspid dihitung dengan menggunakan rumus Bernouli (Gambar 4 kiri). Tekanan sistolik bisa diukur juga dengan mengurangi tekanan darah sistolik dengan gradien trans VSD (Gambar 4 kanan).

\section{Pengukuran tekanan rerata arteri pulmonal}

Pada kondisi tanpa regurgitasi trikuspid maupun defek septal ventrikel (VSD), pengukuran tekanan rerata 
a.pulmonal dapat dilakukan dengan menggunakan waktu akselerasi aliran keluar ventrikel kanan (PV Acct) seperti pada gambar 5 kiri. Tekanan rerata arteri pulmonal juga dapat diukur dengan menggunakan puncak velocity regurgitasi pulmonal dengan rumus $4 \mathrm{~V}^{2}$, seperti terlihat pada Gambar 5 kanan.

\section{Pengukuran tekanan diastolik arteri pulmonal}

Tekanan diastolik arteri pulmonal dapat diukur dari tekanan akhir diastolik aliran regurgitasi pulmonal dengan menggunakan rumus bernoulli dan menambahkannya dengan tekanan atrium kanan seperti terlihat pada Gambar 6.

\section{Perkiraan tekanan atrium kanan}

Cara yang paling praktis untuk memperkiraan tekanan atrium kanan adalah dengan mengukur diameter dan kolapsibilitas vena cava inferior. Struktur ini dilihat dari pandangan subcostal. Diameter IVC diukur pada saat akhir ekspirasi pada lokasi $0,5-3 \mathrm{~cm}$ setelah muara IVC ke atrium kanan, seperti terlihat pada Gambar 7. Cara pengukuran RA ini tidak terlalu akurat pada pasien dalam ventilator.

\section{Resistensi vaskular paru}

Peningkatan RVP yang dianggap signifikan adalah nilai $>3$ WU (Woods Unit). Pengukuran PVR
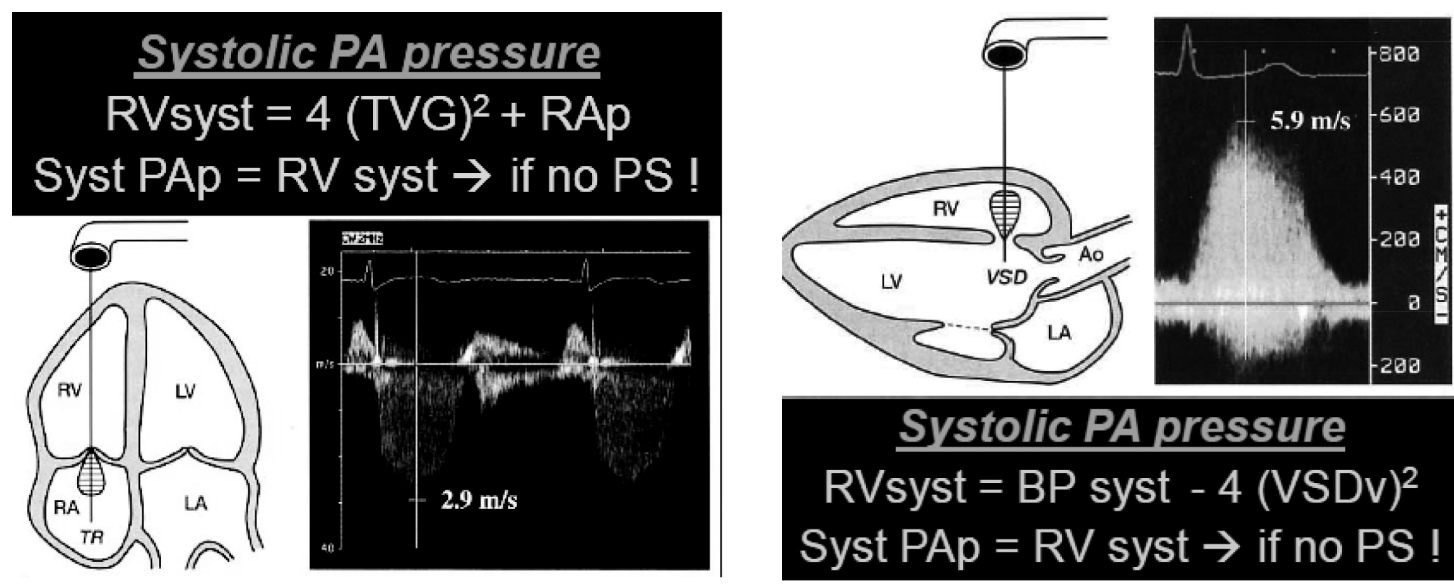

\section{Systolic PA pressure}

RVsyst $=$ BP syst $-4(\text { VSDv })^{2}$

Syst PAp $=$ RV syst $\rightarrow$ if no PS !

Gambar 4. Pengukuran tekanan sistolik ventrikel kanan dengan memanfaatkan gradient regurgitasi trikuspi (kiri) dan gradien trans VSD (kanan).
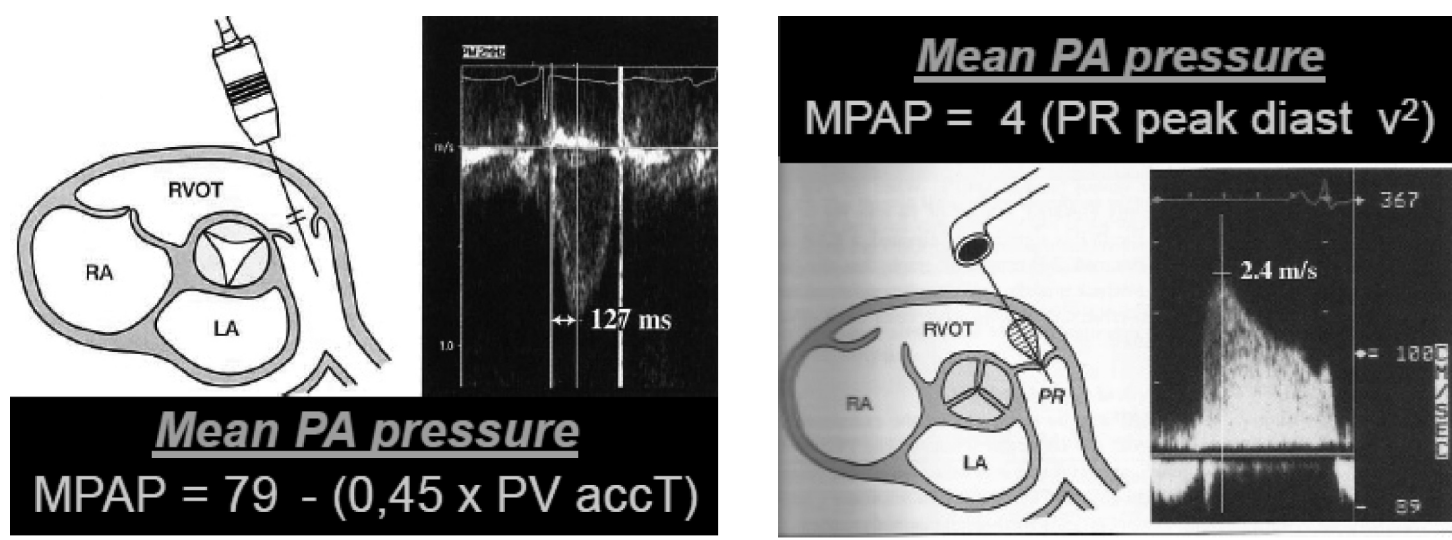

Gambar 5. Pengukuran tekanan rerata arteri pulmonal 


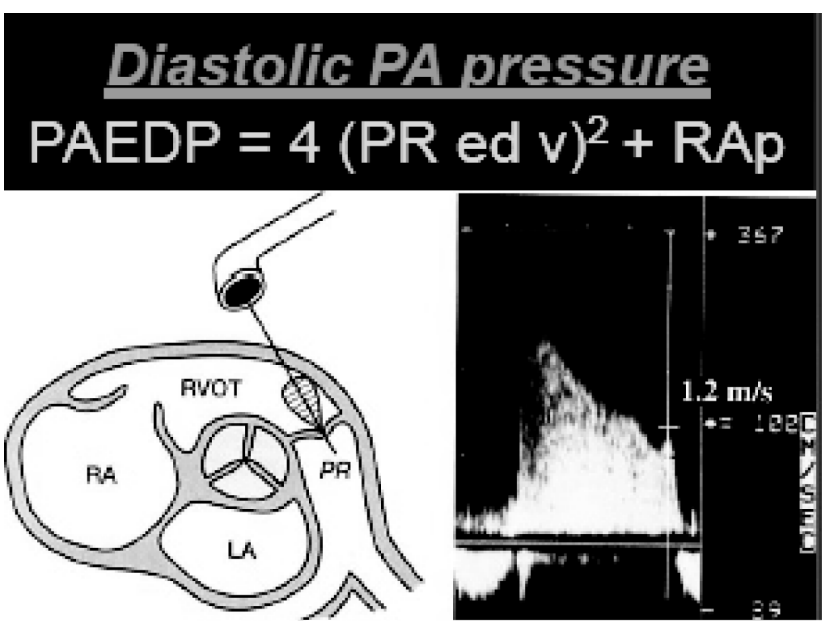

Gambar 6. Cara pengukuran tekanan diastolik arteri pulmonal

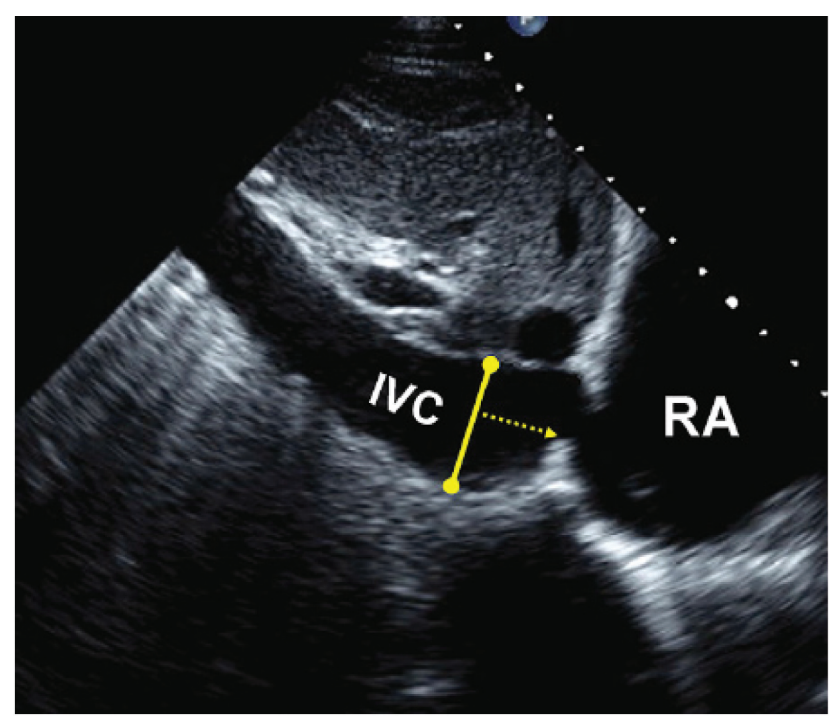

Gambar 7. IVC dan muara RA terlihat pada pandangan dari view ini

Table 1. Perkiraan tekanan atrium kanan dengan menggunakan IVC

\begin{tabular}{|c|c|c|c|}
\hline Variable & Normal $3(0-5) \mathrm{mmHg}$ & Intermediate $8(5-10) \mathrm{mmHg}$ & High $15(10-20) \mathrm{mmHg}$ \\
\hline IVC diameter & $\leq 2.1 \mathrm{~cm}$ & $\leq 2.1 \mathrm{~cm}$ & $>2.1$ \\
\hline Collapse with sniff & $>50 \%$ & $<50 \%$ & $<50 \%$ \\
\hline \multirow[t]{3}{*}{ Secondary indices } & & & Restrictive feeling \\
\hline & & & TV E/e' > 6 \\
\hline & & & $\begin{array}{l}\text { Diastolic flow prediminance in hepatic vein } \\
\text { (syst filling pressure) }\end{array}$ \\
\hline
\end{tabular}

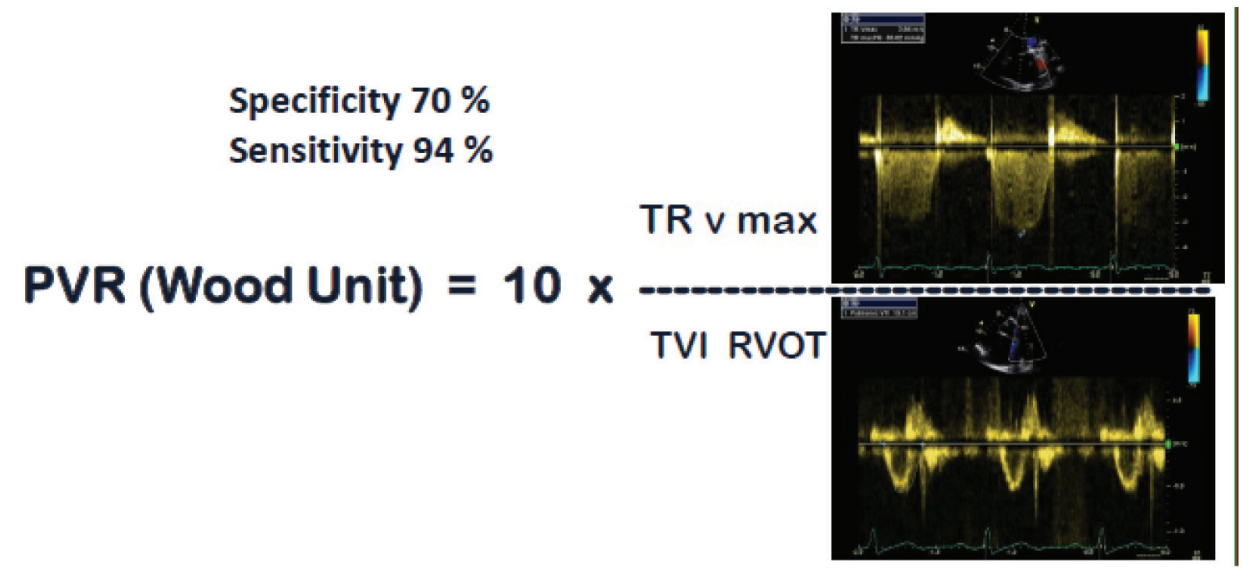

Gambar 8. Resistensi vaskular paru 
dengan ekokardiografi tidak dianggap pemeriksaan hemodinamik rutin. Pemeriksaan RVP dengan ekokardiografi tidak bisa dianggap pengganti pemeriksaan dengan cara invasif. Pemeriksaan RVP dengan ekokardiografi hanya dipergunakan untuk konfirmasi pada pasien dengan peningkatan tekanan arteri pulmoner akibat aliran tinggi atau rendah akibat isi sekuncup yang rendah (Gambar 8).

Demikian pemeriksaan ekokardiografi untuk jantung kanan secara praktis dan singkat yang dapat digunakan untuk kasus-kasus kegawatan atau kritikal.

\section{Daftar Pustaka}

1. Guidelines for the Echocardiographic Assessment of the Right Heart in Adults: A Report from the American Society of Echocardiography Endorsed by the European Association of echocardiography, a registered branch of the European Society of Cardiology, and the Canadian Society of Echocardiography. (J Am Soc Echocardiogr 2010;23:685713.)

2. Anderson B. In : Echocardiography. MGA Graphics Queensland 2002 